\title{
Życie jak scenariusz. Na marginesie książki (Nie)zapomniani dokumentaliści*
}

\author{
JADWIGA HUČKOVÁ \\ Instytut Sztuk Audiowizualnych \\ Uniwersytet Jagielloński w Krakowie
}

\begin{abstract}
Hučková Jadwiga, Życie jak scenariusz. Na marginesie ksiażzi (Nie)zapomniani dokumentaliści [Life like a scenario. Reflections on the margins of the book (Un)Forgotten documentary filmmakers]. "Images” vol. XXIX, no. 38. Poznań 2021. Adam Mickiewicz University Press. Pp. 255-264. ISSN 1731-450X. DOI 10.14746/i.2021.38.16

The book (Un)forgotten documentalists, edited by Katarzyna Mąka-Malatyńska and Jolanta Lemann-Zajiček (2020) is a significant achievement in research on Polish documentary film. The review of the collective work, consisting of ten texts preceded by an introduction, becomes the starting point for discussions with selected authors and reflection on the problem of the absence of significant documentary filmmakers in the history of the film. Entire currents are also forgotten, such as a film about art, represented by four out of nine documentary filmmakers discussed in the book. The meanders of life and creativity can be instructive for contemporary documentary filmmakers.
\end{abstract}

KEYworDs: documentary film, film about art, emigration, Holocaust, Jarosław Brzozowski, Natalia Brzozowska, Tadeusz Makarczyński, Jadwiga Żukowska, Edward Elter, Marian Marzyński, Andrzej Brzozowski, Andrzej Papuziński, Katarzyna Maciejko-Kowalczyk

W latach dziewięćdziesiątych powstały w krótkim czasie dwa dokumenty o identycznym tytule: Życie jak film. Pierwszy, autorstwa Jadwigi Zajiček, zrealizowany w 1994 roku, poświęcony był Jerzemu Bossakowi, a trzy lata później, reżyserowany przez Stanisława Jędrykę - pisarzowi Adamowi Bahdajowi. W odczuciu przedstawicieli środowiska dokumentalistów, reprezentujących średnie pokolenie, to właśnie Bossak wymieniany jest na pierwszym miejscu jako jeden z filmowców niesłusznie zapomnianych. Należy bowiem postawić pytanie, w czyjej świadomości on żyje: reżyserów, którzy mu wiele zawdzięczają i dają temu wyraz (Roman Polański), czy tych, którzy mu wiele zarzucają i z tego powodu nie potrafią zapomnieć? Czy obecny jest przede wszystkim w pamięci historyków filmu[1], którzy starają się dotrzeć do faktów i interpretować je w sposób wyważony? Czy uda się kiedykolwiek zbadać okoliczności jego pobytów w ZSRR, zwłaszcza w latach II wojny światowej? Czy powiedzie się zrekonstruowanie historii współpracy z Jorisem Ivensem, a przy okazji odtworzenie różnych aspek- tów funkcjonowania międzynarodowego lobby dokumentalistów-lewicowców w latach 1940-1980? Wiemy, że Bossak odważył się krytykować największych radzieckich filmowców za schematyzm, ale czy wiemy, kogo podziwiał i mniej lub bardziej świadomie starał się naśladować? Czy uda się zebrać w jedną całość spuściznę teoretyczną, publicystyczną oraz krytyczną Bossaka[2], by ocenić jej wpływ na

* (Nie)zapomniani dokumentaliści, red. K. Mąka-Malatyńska, J. Lemann-Zajiček, Wydawnictwo PWSFTviT im. L. Schillera w Łodzi, Łódź 2020.Recenzję w skróconej formie zob. J. Hučková, Zapomniani czy niezapomniani dokumentaliści? "Kwartalnik Filmowy" 2020, nr 42(112), s. 256-262.

[1] M. Hendrykowski, Jerzy Bossak. Szkic do portretu (1910-1989), „Images” 2017, nr 29, s. 103-118. [2] Wspominam o aktywności teoretycznej Jerzego Bossaka nie bez przyczyny. Interesowali się nią filmowcy i historycy filmu w Czechosłowacji. W spuściźnie jednego ze słowackich dokumentalistów zachowało się tłumaczenie obszernego tekstu Bossaka, którego pierwowzoru nie udało się dotychczas odnaleźć. 
pokolenia uczniów i współpracowników? Zarówno jego znaczenie dla polskiego kina, jak i barwna osobowość nadal nie są wyczerpująco i kompleksowo opisane. W cieniu Bossaka pozostawali wszakże inni, tym bardziej nieobecni dziś reżyserzy, na przykład Ludwik Perski[3], reprezentujący tę samą generację i podobne doświadczenia, nagradzany na festiwalach, o którym wspomina się przede wszystkim jako o redaktorze Polskiej Kroniki Filmowej.

Książka (Nie)zapomniani dokumentaliści inspiruje do dalszych poszukiwań, ponieważ biografii „filmowych” - w sensie niepospolitych, frapujących, obfitujących w dramatyczne zwroty - znalazłoby się w naszej historii kina o wiele więcej. Wszystkie, zawarte w tomie, wpisują się $\mathrm{w}$ taką formułę. Jest to właściwość, która powinna zachęcić do lektury osoby nawet niespecjalnie interesujące się filmem dokumentalnym i która pomoże zaistnieć bohaterom książki w szerszym gronie odbiorców. Barwność sportretowanych postaci w niczym nie umniejsza walorów historyczno-filmowych książki, wręcz je dopełnia: autorzy tomu, zachowując wszelkie standardy naukowe, w wyważony i kunsztow-

[3] Taką opinią podzieliła się Maria Malatyńska, wymieniając wśród „zapomnianych dokumentalistów” również całą galerię usuniętych w cień reżyserek, a wśród nich Aleksandrę Jaskólską, autorkę Niesporczaków (1968), filmu popularnonaukowego, interpretowanego w swoim czasie politycznie.

[4] Paradoks polega na tym, że wraz z likwidacją studiów Kronika i Wir, spadkobierców idei dokumentowania, przerwano tradycję rejestracji dokumentalnych oraz notacji filmowych. Zob. M. Smoleń, Studia Filmowe „Kronika” $i$ „Wir”, czyli kilka uwag na temat produkcji filmów dokumentalnych po roku 1989, „Images” 2013, nr 21-22, s. 59-72.

[5] M. Jazdon, Dokumenty Kieślowskiego, Poznań 2002.

[6] Idem, Kino dokumentalne Kazimierza Karabasza, Poznań 2009.

[7] P. Pławuszewski, Po swojemu: kino Władysława Ślesickiego, Kraków 2017.

[8] U. Tes, Człowiek, zbiorowość, pamięć w filmach dokumentalnych Ireny Kamieńskiej, Kraków 2016. ny sposób łączyli fakty biograficzne z celnymi analizami wybranych filmów. Publikacja zawiera wstęp i dziewięć rozdziałów, poświęconych kolejno Jarosławowi Brzozowskiemu, Natalii Brzozowskiej, Tadeuszowi Makarczyńskiemu, Jadwidze Żukowskiej, Edwardowi Elterowi, Marianowi Marzyńskiemu, Andrzejowi Brzozowskiemu, Andrzejowi Papuzińskiemu, Katarzynie Maciejko-Kowalczyk. Zamykający tom rozdział: „Archeologia mitu. W domu na Chełmskiej i na Kilińskiego" poświęcony jest kilku aspektom funkcjonowania środowiska dokumentalistów, czyli pewnego rodzaju wspólnoty nie tylko zaznaczającej swą obecność podczas festiwali, ale istotnej dla jej członków w codziennej pracy. Interesująca perspektywa stanowi zachętę do dalszych badań i wezwanie do dokonywania notacji filmowych[4], których bohaterami byliby sami reżyserzy.

Dobrze zakomponowana całość składa się na wartościową poznawczo, a jednocześnie fascynującą lekturę, kontynuującą serię znaczących monografii poświęconych Krzysztofowi Kieślowskiemu[5], Kazimierzowi Karabaszowi[6], Władysławowi Ślesickiemu[7], Irenie Kamieńskiej[8], a zarazem podejmującą coraz aktualniejszy problem badawczy: nieobecności bądź słabej obecności pewnych twórców w historii filmu. Znacząca nieobecność wynikała, jak dotychczas, najczęściej z faktu emigracji reżysera z przyczyn politycznych. Kiedy te ustały, twórczość „nomadycznych” autorów, mimo ich sporych zasług (Bolesław Sulik, Jerzy Śladkowski), bywa marginalizowana w narodowych historiach filmu. W świadomości widzów pamięć o aktywnych współcześnie reżyserach trwa, dopóki nie zamilkną działania marketingowe wokół ich dokonań. Problem „zapominania" istnieje nadal, zmieniają się tylko rządzące nim mechanizmy.

Zapomniani i niezapomniani dokumentaliści czekają na odkrycie bądź przypomnienie nie tylko u nas. Biorąc do ręki przedmiotową publikację, czytelnik oczekuje - chociaż lapidarny tytuł nie daje takiej obietnicy - że w ramach kolejnych rozdziałów otrzyma $\mathrm{w}$ miarę pełną sylwetkę dokumentalisty, który objawi 
się przede wszystkim jako człowiek związany z Polską, wychowany lub przynajmniej dobrze orientujący się w polskiej kulturze - niezależnie od indywidualnych kolei losu, uwarunkowań politycznych czy jakiekolwiek innych, które zadecydowały o odseparowaniu od „źródła”. Przyczyny i reperkusje życiowe oraz przede wszystkim twórcze owego oddzielenia również powinny zaistnieć jako temat refleksji, co w przypadku sylwetek emigrantów zostało $\mathrm{w}$ omawianej publikacji spełnione. Bardzo istotnym walorem tekstów staje się zarysowanie wszechstronnej działalności reżyserów, ich doświadczeń i umiejętności nabytych poza Polską, rozwijających znajomość innych kultur - elementów, które pogłębiają rozumienie świata i znajdują wyraz w twórczości. Tylko wówczas ich sylwetki stają się kompletne.

\section{Zdobywcy trofeów, wyklęci i wizjonerzy}

Dobrze się stało, choć wynika to z samych metryk, że tom otwiera nakreślony przez Marka Hendrykowskiego portret Jarosława Brzozowskiego, znanego mi od zawsze jako reżyser filmów o sztuce, a studentom filmoznawstwa kojarzonego z uhonorowaną w Cannes Grand Prix w kategorii krótkometrażowych filmów oświatowych Wieliczka (1946) oraz udziałem (wraz z Jerzym Bossakiem) w realizacji Warszawy 56 , jednego ze sztandarowych dokumentów „czarnej serii”. O randze twórcy świadczy również nagrodzona w Wenecji Helioplastyka (Złoty Lew św. Marka w 1966). Znaczące jest przypomnienie o egzystencji i walorach tego filmu jako studium warunków helioplastycznych, będącym wizualną transpozycją myśli Leonarda da Vinci: „Cień i światło są jedynym środkiem do poznania kształtu ciała” (s. 20). Jakie wartości zadecydowały przed laty o zauważeniu Wieliczki? „Jurorzy docenili oryginalność podjętego tematu, skalę trudności realizacji zdjęć głęboko pod ziemią oraz estetyczną urodę całości” (s. 16). Autor tekstu podkreśla wyjątkową wrażliwość wizualną reżysera, który zaznaczył swą obecność w polskim kinie „dojrzałą, nader nowoczesną jak na owe czasy odmianą eseju dokumentalnego" (s. 15).
Studium o Jarosławie Brzozowskim poprzedzone zostało solidną pracą archiwistyczną. W sąsiadujących z sobą rozdziałach czytelnik otrzymuje znakomicie zarysowane tło historyczne, wojenne oraz powojenne meandry biografii obojga Brzozowskich (kolejno - Jarosława i Natalii), które same w sobie mogłyby stać się punktem wyjścia scenariusza filmowego. W kontekście historii filmu jednostkowe losy dopełniają obraz kinematografii lat czterdziestych i pięćdziesiątych oraz przybliżają złożone okoliczności jej rozwoju. Zasługi Jarosława Brzozowskiego dla sztuki dokumentu, jego prekursorstwo, osobowość artystyczna zyskują ciężar gatunkowy po nakreśleniu przełomowych momentów w biografii. Właśnie dzięki elementom biograficznym, składnie połączonym $\mathrm{z}$ rozwojem twórczym, sylwetka reżysera na kartach książki „ożywa”, staje się pełna, plastyczna. Za osiągnięciami artystycznymi stoi konkretny człowiek.

W artykule mowa jest o represjach politycznych wobec realizatorów Polskiej Kroniki Filmowej. Dotknęły one również Brzozowskiego: „Wyrokiem ogłoszonym 20 grudnia 1948 roku skazano go na sześć lat więzienia. [...] Zasądzoną karę odbywał Brzozowski w mokotowskim więzieniu Ministerstwa Bezpieczeństwa Publicznego przy ulicy Rakowieckiej, następnie w zakładzie karnym w Jaworznie, od 8 września 1949 roku w Rawiczu..." (s. 17-18). Trudno określić, jak wiele treści kryje się za każdym podanym faktem, za pojedynczą, zdobytą przez autora informacją. Akurat ta nie wyczerpuje istoty dramatu, jaki przeżył Brzozowski jako twórca. Aresztowanie łączyło się z odebraniem filmu, którego produkcja była już bardzo zaawansowana. Po wielu miesiącach realizacji zdjęć do Wielkiego redyku (1949) reżyser został aresztowany w Zakopanem. Zarzucono mu utrzymywanie kontaktów szpiegowskich $\mathrm{z}$ agentem angielskiego wywiadu. Decyzją władz Przedsiębiorstwa Państwowego „Film Polski”, personalnie Jerzego Bossaka, film ukończył Stanisław Możdżeński i to jego nazwisko pojawiło się $\mathrm{w}$ napisach i widnieje $\mathrm{w}$ bazach filmowych; o Brzozowskim nie wspomina się 
do dziś w większości z nich[9]. Dzieło, zmontowane przez Możdżeńskiego i Wacława Kaźmierczaka, wysłane na festiwal do Cannes, otrzymało nagrodę za zdjęcia[10] autorstwa Sergiusza Sprudina.

Najtragiczniejszą bohaterką książki jest Natalia Brzozowska: „mistrzyni dokumentu poetyckiego" [11], znana przede wszystkim jako autorka Kopalni (1947), dokumentu zakwalifikowanego na Festiwal Filmowy w Wenecji. W przypadku tej reżyserki również mamy do czynienia ze świetnie zapowiadającą się karierą, złamaną przez okoliczności polityczne. „[N]owatorski i poniekąd prekursorski - krótki metraż oddziałał na dalsze poszukiwania twórców rodzimego dokumentu artystycznego" czytamy w tekście (s. 35). Podczas zjazdu filmowców w Wiśle, po tym, jak Brzozowską

[9] Nazwisko Brzozowskiego nie występuje również w większości baz w związku z filmem $A b a-$ kany (1970), jednym z najbardziej przejmujących filmów o sztuce, w którym pojawia się osobiście Magdalena Abakanowicz. Kwestię autorstwa i w tym wypadku naświetla Marek Hendrykowski w swoim tekście. Jest to cenna informacja, wyjaśniająca konsekwencję poszukiwań twórczych Brzozowskiego. Równie ważna jest właściwa atrybucja: Abakany powszechnie włączane są w ramy dorobku filmowego Kazimierza Muchy.

[10] „Nagroda ta jest tym cenniejsza, iż na ogólną liczbę 75 krótkometrażówek wyświetlanych na Festiwalu, tylko 6 zostało wyróżnionych". Z. Pitera, Sukces krótkiego metrażu, „Film” 1949, nr 19 (75), s. 11.

[11] M. Hendrykowski, Dokument po wojnie. Lata 1945-1955, [w:] Historia polskiego filmu dokumentalnego 1945-2014), red. M. Hendrykowska, Poznań 2018, s. 53.

[12] Cyt. za: J. Lemann-Zajiček, Kino i polityka. Polski film dokumentalny 1945-1949, Łódź 2003, s. 248.

[13] Film Katarzyny Maciejko-Kowalczyk Benek Blues (1999), którego bohaterem jest fotografik Bernard Dobrowolski, pozwala wpisywać największe jej dokonanie reżyserskie w ramy tego nurtu. Podobnie mamy prawo zaklasyfikować film Jaki jest z bliska (2004), poświęcony Andrzejowi Wajdzie, którego portret kreślą Krystyna Zachwatowicz, Agnieszka Holland, Barbara Pec-Ślesicka i Krystyna Janda. oskarżono o „formalistyczną metodę maskowania wrogiej ideologii” (s. 38), reżyserka złożyła samokrytykę. Formuła tej wypowiedzi pozostaje dobitnym świadectwem upodlenia, do jakiego doprowadzono autorkę Kopalni:

W okresie pracy nad filmem miałam tendencję do formalizmu. Prawie we wszystkim, co dotąd robiłam - mało mnie obchodziła treść [...]. Od czasu, kiedy zaczęłam się interesować sprawą ideologii socjalistycznej [...] zupełnie zmieniło się moje podejście nie tylko do treści, ale zmienił się mój stosunek do formy. Dziś patrząc na moje filmy czuję obcość[12].

Najmocniej przemawia osobisty dramat odsunięcia od zawodu, jeśli się zważy nie tylko pogrzebany talent, ale i konieczność utrzymywania trzyosobowej rodziny, w latach, w których Jarosław Brzozowski przebywał w więzieniu. Konsekwencją było załamanie psychiczne i poddanie się zwykłej ludzkiej słabości, prowadzącej najpierw do „swoistej konwersji ideologicznej" (s. 39), o której świadczą scenariusze pisane na początku lat pięćdziesiątych, a w końcu, w odwecie za własną złamaną karierę - do ataku personalnego skierowanego przeciw wszechwładnemu w ówczesnym systemie kinematografii Aleksandrowi Fordowi.

\section{Bliżej sztuki}

Co najmniej czworo[13] z dziewięciorga (nie)zapomnianych dokumentalistów to znani autorzy filmów o sztuce. Biografię twórczą Tadeusza Makarczyńskiego niezrównanie udokumentowała i nakreśliła Jolanta Lemann-Zajiček. Reżyser dał się poznać jako autor filmów o sztuce przede wszystkim dokumentami Kantyczka z drewna (1958), o twórczości Leona Kudły, Spotkanie z Teofilem Ociepka (1962), Mistrza Canaletta przewodnik po stanisławowskiej Warszawie (1983), Warszawa Aleksandra Gierymskiego (1984), Autoportret artysty (1985); motywy z obrazów Pietera Bruegla Starszego znajdziemy w filmie Życie jest piękne (1957). Światową sławę zdobyła Suita warszawska (1947) z muzyką skomponowaną do filmu przez Witolda Lutosławskiego. Reżyser, warszawianin z wyboru, opowiadał po latach: 
Nie mogę o tym zapomnieć, mimo że minęło czterdzieści lat. Podczas mojej pracy za granicą próbowałem na ten temat mówić z Francuzami, Anglikami, Szwajcarami. [...] Wrócili do swych nienaruszonych domów, do swoich zawodów, interesów, dzieci i żon, które na nich spokojnie czekały. Wojna była dla nich zamkniętym epizodem [...]. Na nas wojna zostawiła ślad nie do wytarcia (s. 81).

Gorzkim paradoksem jest fakt, że jeden z filmów Makarczyńskiego, Życie jest piękne (1957), nabiera właśnie aktualności i można go na nowo odczytywać w kontekście powszechnych obaw przed niewiadomą przyszłością. Zwróciła moją uwagę eksplikacja tego dzieła wydobywająca na nowo odczytywane jego walory, zwłaszcza rolę muzyki. To analiza prowadząca do odkrycia sensów głębszych od powszechnie mu przypisywanych. Istotnym elementem znaczeniowym w tym dziele są "obrazy zbiorowej niepamięci” (s. 67), jak je nazwała autorka studium. Życie jest piękne to przejaw lęku, protest wykrzyczany wtedy, kiedy pojawiła się - jak mówił Makarczyński - „zupełnie nie do objęcia umysłem możliwość zagłady totalnej” (s. 67). Również współcześnie jego film można odczytać jako wielkie wołanie o życie.

\section{Reżyserki - o artystach}

Studium Katarzyny Mąki-Malatyńskiej poświęcone Jadwidze Żukowskiej również nosi wyraźne piętno autorskie, a osobisty ton narracji okazuje się wyjątkowo adekwatny. Osoby, które pamiętają Żukowską, z pewnością potrafią ją rozpoznać w nakreślonym wizerunku. Podczas Krakowskiego Festiwalu Filmowego, bodaj ostatniego z jej udziałem, kiedy sala kina „Kijów” rozświetliła się na moment pomiędzy projekcjami i rozpoczął zwykły ruch związany z przemieszczaniem się części widzów, Żukowska zawołała: „nie wychodźcie, teraz będzie mój film!”. Apel był tak rozbrajający, że wielu widzów pozostało na widowni. Filmy Żukowskiej poświęcone baletowi - Duet (1988), Teatr tańca według Adama Hanuszkiewicza (1990) - należą do największych osiągnięć poświęconych tej tematyce. Dokumenty na temat artystów i ginących rzemiosł artystycznych, które tworzyły atmosferę przeglądów filmów o sztuce, warto byłoby przypominać również ze względu na zdjęcia autorstwa Stanisława Śliskowskiego. Obok dwóch najważniejszych nurtów tematycznych twórczości Żukowskiej - tematu dzieci oraz filmów o sztuce - autorka biografii odkrywa i analizuje również mniej znaną stronę aktywności zawodowej reżyserki - filmy morskie. Fakty biograficzne z życia reżyserki, przeżyte dramaty (śmierć syna), wplecione zostały z wielkim taktem w biografię artystyczną.

Potrzeba było wyjątkowej wrażliwości, by przybliżyć postać montażystki i reżyserki, która, jako reżyserka właśnie, „mogła się nigdy nie wydarzyć" (s. 229). Taką predyspozycją wykazał się Piotr Pławuszewski jako autor studium poświęconego Katarzynie Maciejko-Kowalczyk, będącego pierwszą próba całościowego spojrzenia na twórczość wybitnej autorki. Tekst skupia się nie tylko na odczytaniach najbardziej znanego i nagradzanego filmu Benek Blues (1999), ale przywraca i wydobywa walory późniejszych dokumentów Co czuje bocian (2003) i Jaki jest $z$ bliska (2004), sytuując je w kontekście filmów o podobnej tematyce, jak i w kontekście szerzej rozumianej kultury. Pewne refleksje, które rodzą się podczas lektury pozostałych biografii twórczych zawartych w książce, znajdują potwierdzenie w tekście Pławuszewskiego. Dotyczą one pejzażu polskiej krytyki filmowej - chodzi o artykuły z prasy filmowej oraz codziennej, przytaczane w poszczególnych rozdziałach tomu. Ich autorzy odnoszą się do różnych sądów, dyskutują z cytowanymi recenzentami, zdarza się, że wytykają im powierzchowność odbioru, zwykłą tendencyjność. Od perspektywy przyjętej przez krytyka, użytych przez niego sformułowań, forsowanego stanowiska zależy istnienie bądź nieistnienie filmu, bywa, że i reżysera. Współczesny osąd wpływa na odczytanie twórczości przez najbliższe lata. Decydująca staje się optyka, jaką wybiera dla siebie autor monografii/eseju/biografii twórcy. Może twierdzić coś z całą pewnością, nie zważając, czy posiadana wiedza i zrozumienie dzieła nie dają mu prawa, by co najwyżej - przypuszczać. „To ta wspomniana subtelność: tekstu 
komentarza («wydaje mi się» zamiast «wiem») i decyzji, by o dojściu do pewnego wniosku poinformować zza kadru («z dystansu»)" (s. 253). Lektura tekstu Pławuszewskiego przywodzi na myśl witruwiański termin dekor, czyli stosowność, zgodność wykorzystanych elementów $\mathrm{z}$ charakterem konstrukcji dzieła.

\section{Emigranci i reemigranci, podróżnicy w głąb duszy}

Równoległym wątkiem rozważań, przewijającym się w tle kolejnych rozdziałów, jest rola Wytwórni Filmów Dokumentalnych i Wytwórni Filmów Oświatowych (w której powstawały również filmy Jadwigi Żukowskiej) i wpływ atmosfery twórczej w nich panującej na eksperymenty podejmowane przez reżyserów. Najbardziej enigmatyczną postacią niniejszego zbioru, także dla filmoznawców, jest Edward Elter. Krzysztof Jajko, autor studium na jego temat, upatruje jeden $z$ powodów jego nieobecności w polskim dyskursie filmoznawczym w związaniu się reżysera z wytwórnią, która (podobnie, choć niesłusznie - jak i WFO) nie jest w powszechnym odczuciu spajana $\mathrm{z}$ filmem dokumentalnym: Studio Małych Form Filmowych Se-Ma-For. Elter, jak i Marzyński należą do emigrantów pomarcowych, co wyznacza główną ścieżkę interpretacji ich twórczości. Bez odniesień do faktów biograficznych próby analizy dorobku zarówno Eltera, jak i Marzyńskiego nie będą kompletne.

W roku 1962 debiutancki dokument Eltera Cmentarz Remu nagrodzony został Srebrnym Żaglem na festiwalu w Locarno w dziale filmów krótkometrażowych, tym samym potwierdza-

[14] Celowo przypominam opinię jednego z krytyków, wyrażoną w swoim czasie na temat książki Jazdona poświęconej Kazimierzowi Karabaszowi (M. Jazdon, Kino dokumentalne...): „ma szczęście, że ma Mikołaja Jazdona - inteligentnego, wnikliwego widza, filmoznawcę", J. Socha, Mikołaj Jazdon, Kino dokumentalne Kazimierza Karabasza, Dwutygodnik.com 4/2010; <https:// www.dwutygodnik.com/artykul/1029-mikolaj-jazdon-kino-dokumentalne-kazimierza-karabasza.html>, dostęp: 27.12.2020. jąc format reżysera. Autor studium przedstawia znakomitą analizę tego filmu i prezentuje pozostałe dzieła filmowe Eltera w kontekście jego aktywności jako recenzenta filmowego. $\mathrm{Na}$ uwagę zasługuje objawienie czytelnikowi filmowych improwizacji, realizowanych jako filmy instruktażowe (!): Okolice peronów (1964), Fabryka bez dachu (1966), a zwłaszcza wyeksponowanie ich warstwy muzycznej. Otwartość reżysera na formy eksperymentalne zostaje uznana za „artystyczną wizytówkę przemian, jakie w latach sześćdziesiątych dokonywały się w Se-Ma-Forze i WFO. Chodzi tu przede wszystkim o gatunkowe bogactwo konwencji, po które sięgał Etler" (s. 126). Najbardziej zapomniany z zapomnianych reżyserów znalazł godnego egzegetę swej twórczości.

Słowa te można odnieść do reżysera najsilniej obecnego z (nie)zapomnianych, czyli Mariana Marzyńskiego, który znalazł w osobie Mikołaja Jazdona interpretatora nadzwyczaj wnikliwego i uczciwego[14]. Autor, zaznajomiony gruntownie z licznymi dokonaniami filmowymi Marzyńskiego, jak i jego wypowiedziami, nie wartościuje ich etycznie, nie poddaje również osądowi samych eksperymentów medialnych z różnych etapów bogatej twórczości. Przedstawia różnorodność stanowisk i włącza je w tok rozważań, przywołując najważniejsze głosy krytyczne. Tekst wpisuje się w niegasnącą dyskusję zarówno na temat etyki w dokumencie, jak i złożonych aspektów przedstawiania relacji polsko-żydowskich w filmie. Na podkreślenie zasługuje rzeczowość argumentacji oraz wyważenie opinii.

Trzeci, kolejny z rzędu rozdział książki sytuuje się tematycznie w kręgu Holocaustu i stosunków polsko-żydowskich, co jest efektem skupienia się na jednym tylko wątku twórczości Andrzeja Brzozowskiego. Tadeusz Szczepański świetnie poprowadził analizę wybranego „monotematu” (s. 192). Autorzy pozostałych tekstów tomu prezentują jednak w miarę wszechstronną aktywność twórców (reżyserską, krytyczną, pedagogiczną) i próbują się odnieść do pełnej filmografii reżyserów. Nie wspominając o całych nurtach (filmy o sztuce), wątkach, faktach biograficznych, podróżach, jak i wszystkim, co 
miało wpływ na - jednak - różnorodność tematyczną. Nie widzę Brzozowskiego jako autora filmów powstałych w Azji (Wietnam, Laos, Japonia) - kto i kiedy o nich opowie? Nie dostrzegam jako pedagoga i opiekuna artystycznego tylu znakomitych etiud.

Brakuje Brzozowskiego jako reżysera Poboczy (1975) i nagradzanego na międzynarodowych festiwalach dokumentu o niewidomych dzieciach To jest jajko (1965), ale przede wszystkim jako twórcy Hotelu. Calendarium (1982) - filmu będącego metaforyczną opowieścią o Polsce w XX wieku, w niezwykły sposób wyrażającą atmosferę stanu wojennego[15]. Dokument przez lata był zatrzymany przez cenzurę, a jednak istniał w środowisku, przynajmniej w pamięci kolegów-reżyserów. Historia warszawskiego hotelu Bristol, otwartego w roku 1901, to opowieść o dekadach jego przedwojennej świetności i powojennej degradacji. Z perspektywy roku 1982 wspomnienie wielkich nazwisk przywołuje na myśl zagrożone wartości sztuki, nauki, postawy obywatelskiej, patriotyzmu, których nosicielami byli znakomici goście (Maria Skłodowska-Curie, Ignacy Jan Paderewski, Józef Piłsudski, Wojciech Kossak). Przedwojenne bale filantropijne w Bristolu zastąpiły w czasach komunizmu zabawy innej klasy, ale nie to jest najbardziej uderzające. Zasługą Brzozowskiego jest przypomnienie o balach sylwestrowych z przełomowych lat 1956/1957, 1968/1969 i wreszcie sylwestra po masakrze robotników na Wybrzeżu w roku 1970. Kiedy środowisko dokumentalistów powoli się rozpływa, co zresztą wybrzmiewa w rozdziale zamykającym tom - kto przypomni kolejnym generacjom o podobnych dokumentach?

\section{Filmowy Olimp}

Andrzej Papuziński, autor filmów o sztuce, to „artysta elitarny w najlepszym tego słowa rozumieniu. Wymagający także wobec widza. Oczekuje od niego kompetencji kulturowej, wrażliwości, odbiorczej empatii, umiejętności czytania kodów kultury, otwartości” (s. 223). Jego osoba zobowiązywała do podejścia szczególnego i rozległych kompetencji. Tekst
Małgorzaty Hendrykowskiej, zawierający wielowarstwowe eksplikacje filmów, będących arcydziełami gatunku, przyciąga uwagę przede wszystkim kunsztem interpretacyjnym. Właśnie rozbudowana interpretacja utworów stanowi o wyjątkowości studium.

Papuziński reprezentował nurt kreacyjny w polskim filmie o sztuce i właśnie jemu udało się przybliżyć istotę twórczości Franciszka Starowieyskiego (Bykowi chwała, 1971) czy Tadeusza Brzozowskiego (Brzuch, 1979). Autorka wręcz inspiruje do podjęcia dyskusji, które z dzieł sztuki „drugiego stopnia”[16] jest bardziej wysublimowane, nie tracąc swych walorów dokumentalnych - Bykowi chwała czy Brzuch? Moim zdaniem jest to film o Brzozowskim, analizowany książce jako „dużo bardziej osobisty, opowiadający mniej o twórczości, bardziej o drodze twórczej, fascynacjach, wyborach w kontekście prywatnych doświadczeń artysty" (s. 217). Chcę zwrócić uwagę na inny wątek.

O ile twórczość Starowieyskiego próbował opisać archiwista i reżyser, jak to przedstawia w analizie Małgorzata Hendrykowska, to przy obrazach Brzozowskiego powołano już cały chór „egzegetów”. Na pierwszy plan wysuwa się jednak sam bohater, dawny aktor teatru Tadeusza Kantora, który ze znamienną dla malarza lekką rezerwą gra samego siebie[17]. $\mathrm{W}$ przełomowym momencie filmu sięga po buławę i przywdziewa purpurę. Jako komediantowi wolno mu było użyczyć sobie tych oznak władzy, dostąpić zaszczytu bycia jed-

[15] J. Hučková, Opowieści naocznego świadka: kino pomiędzy wiosnami Solidarności, [w:] Historia polskiego filmu dokumentalnego (1945-2014), red. M. Hendrykowska, Poznań 2015, s. 396.

[16] Według Bazina skończone dzieło sztuki, które samo sobie wystarcza, film „zastępuje dziełem II stopnia, rzucając nań nowe światło". A. Bazin, Film i rzeczywistość, Warszawa 1963, s. 109.

[17] J. Głowa, Klasyka polskiego filmu o sztuce. Dwie tendencje, „Estetyka i Krytyka” 2007/2008, vol. 13/14, nr 2/1, s. 47-61, <https://pjaesthetics. uj.edu.pl/documents/138618288/139072467/ eik_13-14_3.pdf/301e77ff-4043-4541-ba102fa6cbf8efga $>$, dostęp 23.10.2020. 
nocześnie hetmanem i królem, przypominającym postać z obrazu Prorok z 1950 roku. Zderzenie liturgii z kabotyństwem, traktowanie życia jako zabawnego i strasznego spektaklu można odnaleźć w dziełach malarskich Brzozowskiego oraz rysunkach $\mathrm{z}$ gatunku persyflażu. Papuziński objaśnia, za pośrednictwem artysty, malarstwo poprzez teatr, który stopniowo transformuje się $\mathrm{w}$ parodię opery, jaką są głosy różnych interpretatorów. $\mathrm{W}$ istocie to reżyser zaznacza dystans wobec własnych osiągnięć w kwestii przybliżenia widzowi prawdy o artyście. Piękny przykład autoironii na wyżynach sztuki.

\section{Branżowi „dostawcy mitów” \\ i ich mitologie}

Tom zamyka artykuł Anny Wróblewskiej opierający się na ciekawym pomyśle analizy mitów, jakie narosły wokół wiodących wytwórni filmowych (Wytwórnia Filmów Oświatowych w Łodzi i Wytwórnia Filmów Dokumentalnych w Warszawie). W pamięci reżyserów „wytwórnia na Chełmskiej staje się światem idealnym, małą ojczyzną, punktem wyjścia i przestrzenią familijnych relacji” (s. 266). Świadectwem tego są wywiady własne autorki z filmowcami rywalizujących z sobą ośrodków: łódzkiej WFO, otwartej na pomysły i zapewniającej wolność twórczą, oraz warszawskiej WFD. Mit tej drugiej nie uratował idei. Przerwano tradycję notacji filmowych i rejestracji dokumentalnych, zlikwidowano studia Kronika oraz Wir, zamknął się tym samym wielki rozdział historii polskiego dokumentu. Może ta okoliczność tym intensywniej wzmaga żywotność samego mitu?

\section{Filmowy bedeker}

Co z lektury tomu wynika dla współczesnych dokumentalistów, a zwłaszcza filmowców młodego pokolenia? Zdajemy sobie sprawę, że wyzwania współczesności są odmienne. Zasadnicza część, albo w niektórych przypadkach i całość aktywności twórczej omówionych w książce dokumentalistów przypada na czasy, w których pozycję i nazwisko wypracowywało się przede wszystkim poziomem filmów; dziś trudno sobie wyobrazić zaistnienie w świadomości odbiorców bez działań marketingowych, różnego rodzaju agencji zajmujących się lansowaniem filmów, bez otwartego lobbingu. Dokumenty i etiudy studenckie stają się obecne, zwłaszcza za granicą, dzięki akcjom promocyjnym zainicjowanym przez powołane do tego celu instytucje. W jaki inaczej sposób komisja selekcyjna festiwalu, na który napływa kilka tysięcy zgłoszeń, wyłowi to jedno jedyne, wysoce artystyczne, będące wyrazem talentu i efektem wysiłku twórczego? Inny wymiar mają również dzisiejsze nagrody festiwalowe. Klasa trofeów zdobytych przez Jarosława Brzozowskiego czy Andrzeja Papuzińskiego jest tym czynnikiem, który najbardziej przemawia do studentów oraz młodych reżyserów, dzisiejszych zdobywców nagród. Doniesienia medialne o ich przyznaniu nie budzą powszechnych emocji jak niegdyś depesze sprawozdawców z Cannes czy z Wenecji - i giną w powodzi informacji, w kontekście setek odbywających się w świecie przeglądów konkursowych. Spoglądając z jeszcze innej perspektywy - ilu zapomnianych dokumentalistów znaleźlibyśmy na przykład wśród laureatów Złotych Lajkoników i Złotych Smoków Krakowskiego Festiwalu Filmowego, czy dawnych Festiwali Filmów Krótkometrażowych?

Dla autorów w każdych czasach znacząca, a nawet kluczowa jest bezpośrednia reakcja odbiorców, możliwość dyskusji, odzew środowiska. Niegdyś jego poparcie, choćby tylko moralne, wspólne deklaracje i protesty, jeśli film miał problemy z cenzurą, stawały się niezastąpione. Film funkcjonował w świadomości, nawet jeśli nie był pokazywany oficjalnie na ekranach. Obecnie środowisko filmowe jest na tyle zatomizowane, że trudno wyobrazić sobie podobne reakcje, co nie zmienia faktu, że warto walczyć o formułę dyskusji wykraczającą poza festiwalowe Q\&A.

Książka (Nie)zapomniani dokumentaliści staje się zapisem innej rzeczywistości również z tego względu, że w ciągu powojennych dekad odmiennie niż dziś definiowano rolę dokumen- 
tu, odmienna również była pozycja społeczna artystów. Większość bohaterów tomu to ludzie należący do elity w tym sensie, że odbiór ich filmów wymaga aktywności widza, jego przygotowania, kompetencji kulturowych. Dotyczy to zwłaszcza autorów filmów o sztuce. Andrzej Papuziński, nagradzany na najbardziej prestiżowych festiwalach filmowych od Paryża, Wenecji i Cork po Melbourne, Bilbao i Asolo, paradoksalnie najmniej znany szerokiej publiczności, pozostawał do końca życia konsekwentny w swym przywiązaniu do (nie)zapomnianego gatunku, który był polską specjalnością.

Dlaczego i pozostali dokumentaliści są tak słabo obecni w świadomości widzów (podobnie jak całe nurty): Jarosław Brzozowski, nagrodzony na festiwalach w Cannes i Wenecji, Natalia Brzozowska, która „wyprzedzała o cała epokę późniejsze poszukiwania swoich kontynuatorów i następców w sferze kreowania ekspresji audiowizualnej kina” (s. 34), Tadeusz Makarczyński, autor Suity warszawskiej, znanej swego czasu bardziej za granicą niż w Polsce? Powtórzę opinię, wyrażoną w pracy Polski dokument $i$ animacja $w$ XXI wieku[18]: film dokumentalny pozostaje marginesem w programach studiów filmoznawczych, bywa przedmiotem nieobowiązkowym, pomimo że znaczna część absolwentów tego kierunku ma z nim do czynienia w swej karierze zawodowej, znajdując zatrudnienie $\mathrm{w}$ mediach, przy festiwalach i w prasie filmowej. Kto napisze po latach kolejne rozdziały historii (nie)zapomnianych dokumentalistów? Skąd krytycy wyprowadzą systemy ocen, $\mathrm{z}$ jakich dzieł, jeśli nie będą mieć świadomości, że najodważniejsze eksperymenty w dziedzinie dokumentu rozpoczęły się przed stu laty? Czy straciło aktualność przekonanie, że teorie, dyrektywy dominujące tendencje przemijają, a pozostają filmy i to one są dla krytyka skarbnicą?

Już same biografie bohaterów tomu są niezwykłe, a ich meandry mogą stać się pouczające również dla współczesnych. Przestrzeń pomiędzy polityką i filmem, władzą i ambicją artystyczną jest strefą stałych konfrontacji, zmuszających do dokonywania trudnych wyborów. W większości rozdziałów udało się nakreślić pełnokrwiste postaci dokumentalistów, jeśli znanych - to z powodu sukcesów artystycznych oraz aktywności środowiska, które zapewniało reakcje zwrotne i dyskusje wokół projektów. Atmosferę tych czasów przywołuje ostatni rozdział, przybliżają ją również fotografie; książka jest bogato ilustrowana zdjęciami z planów, kadrami filmowymi, wreszcie portretami twórców. Poznajemy ich jako ludzi zmagających się z oporem materii i przeciwnościami losu. Uprawiali zawód reżysera filmowego, pokonując je bądź przegrywając, zachowując niezłomność charakteru albo wikłając się w gry środowiskowe, rzucając oskarżenia, lub umierając z krzywdzącym piętnem donosiciela. Jeśli dodamy fakty przymusowej emigracji, odłączenia od „źródła”, otrzymujemy bogatą skalę ludzkiego doświadczenia, które nie zawsze i nie w każdym aspekcie przejawiło się w twórczości: generacja dokumentalistów, poprzedzająca tę współczesną, nie wynosiła wszystkiego na targ.

Źródło jest tytułem najbardziej znanego filmu Tadeusza Jaworskiego. Warto zdobyć się na benedyktyński wysiłek zgromadzenia rozproszonych materiałów i nakreślenia sylwetki twórcy, podróżnika, wreszcie emigranta, człowieka o niezwykle barwnym życiorysie. Również autora zrealizowanych jeszcze w Polsce filmów o sztuce (a to zaledwie cząstka jego bogatej twórczości), nagradzanego w Wenecji, Rzymie, Mannheim, nominowanego do Oscara już podczas pobytu na emigracji. Galeria zapomnianych dokumentalistów wzbogaca się corocznie, chociaż z drugiej strony wśród najmłodszych filmoznawców można zaobserwować zainteresowanie dokumentami spoza głównego nurtu. Oby ich pasja poznawcza miała szansę się rozwijać.

[18] J. Hučková, Promocja i dystrybucja polskich filmów krótkometrażowych, dokumentalnych $i$ animowanych na przykładzie działalności Krakowskiej Fundacji Filmowej, [w:] Polski dokument i animacja w XXI wieku, red. J. Szczepański, M. Kozubek, Łódź 2016, s. 241-255. 
B I B L I O G R A F I A

Bazin A., Film i rzeczywistość, Warszawa 1963

Głowa J., Klasyka polskiego filmu o sztuce. Dwie tendencje, „Estetyka i Krytyka” 2007/2008, vol. 13/14, nr 2/1, s. 47-61, <https://pjaesthetics.uj.edu.pl/ documents/138618288/139072467/eik_13-14_3. pdf/301e77ff-4043-4541-ba10-2fa6cbf8ef9a>

Hendrykowski M., Jerzy Bossak. Szkic do portretu (1910-1989), „Images” 2017, nr 29, s. 103-118. DOI: https://doi.org/10.14746/i.2017.29.6

Hendrykowski M., Dokument po wojnie. Lata 1945-1955, [w:] Historia polskiego filmu dokumentalnego (19452014), red. M. Hendrykowska, Poznań 2018, s. 15-85

Hučková J., Opowieści naocznego świadka: kino pomiędzy wiosnami Solidarności, [w:] Historia polskiego filmu dokumentalnego (1945-2014), red. M. Hendrykowska, Poznań 2015

Hučková J., Promocja i dystrybucja polskich filmów krótkometrażowych, dokumentalnych $i$ animowanych na przykładzie działalności Krakowskiej Fundacji Filmowej, [w:] Polski dokument i animacja $w$ XXI wieku, red. J. Szczepański, M. Kozubek, Łódź 2016, s. $241-255$

Jazdon M., Dokumenty Kieślowskiego, Poznań 2002

Jazdon M., Kino dokumentalne Kazimierza Karabasza, Poznań 2009

Lemann-Zajiček J., Kino i polityka. Polski film dokumentalny 1945-1949, Łódź 2003

Pitera Z., Sukces krótkiego metrażu, „Film” 1949, nr 19 (75), s. 11

Pławuszewski P., Po swojemu: kino Władysława Ślesickiego, Kraków 2017

Smoleń M., Studia Filmowe „Kronika” i „Wir”, czyli kilka uwag na temat produkcji filmów dokumentalnych po roku 1989, „Images” 2013, nr 21-22, s. 59-72

Socha J., Mikołaj Jazdon, Kino dokumentalne Kazimierza Karabasza, Dwutygodnik.com 2010, nr 4, <https://www.dwutygodnik.com/artykul/1029-mikolaj-jazdon-kino-dokumentalne-kazimierza-karabasza.html>

Tes U., Człowiek, zbiorowość, pamięć w filmach dokumentalnych Ireny Kamieńskiej, Kraków 2016 